\title{
PENDAMPINGAN PROSES INTENSIFIKASI USAHA PEMELIHARAAN ITIK MELALUI IMPLEMENTASI TEKNOLOGI BUDIDAYA INTENSIF DI PETERNAK ITIK LOKAL BOYOLALI, JAWA TENGAH
}

\author{
Wara Pratitis Sabar Suprayogi'1), Novi Akhirini'1), Rendi Fathoni Hadi1), \\ Wahyu Setyono'), Agung Irawan')
}

${ }^{1)}$ Program Studi D3 Budi Daya Ternak, Sekolah Vokasi Universitas Sebelas Maret, Surakarta 57126 Indonesia

Corresponding author : Wara Pratitis Sabar Suprayogi

E-mail : wara.pratitis@staff.uns.ac.id

Diterima 07 Juli 2021, Direvisi 18 Juli 2021, Disetujui 19 Juli 2021

\begin{abstract}
ABSTRAK
Profit yang dihasilkan dari usaha budidaya itik dipengaruhi oleh manajemen budidaya yang diterapkan oleh peternak. Melalui proses identifikasi masalah dengan observasi dan Focus Group Discussion (FGD), pendampingan proses intensifikasi budidaya dilakukan untuk membekali peternak itik lokal dalam melakukan program budidaya itik yang lebih baik. Tujuan pendampingan usaha budidaya yaitu untuk meningkatkan pengetahuan peternak itik terkait dengan operasional usaha budidaya secara intensif sehingga peternak dapat meningkatkan keuntungan dan keberlangsungan usaha. Metode yang dilakukan adalah melalui pendampingan usaha intensifikasi yang meliputi pelatihan manajemen pemeliharaan itik, sanitasi dan biosecurity, manajemen kandang, pembuatan ransum, manajemen kesehatan, serta proses pemasaran ketika itik pedaging dipanen. Proses pendampingan dilakukan dengan pemeliharaan 300 ekor itik lokal Boyolali selama 45 hari dalam dua siklus produksi. Output yang diperoleh dari proses intensifikasi usaha budidaya ini antara lain adanya perbaikan standar sanitasi dan litter kandang. Selain itu, hasil panen yang diperoleh dapat ditingkatkan sesuai dengan standar performa itik lokal Boyolali, yaitu diperoleh rerata bobot panen sebesar 1,21 kg dengan nilai konversi pakan (feed conversion ratio, FCR) sebesar 3,28 dengan tingkat kematian sebesar $3,8 \%$. Keuntungan yang diperoleh dari usaha budidaya itik intensif rata-rata adalah sebesar Rp. 1.783 .500 dalam setiap periode. Disimpulkan, pemeliharaan itik intensif memberikan dampak pertumbuhan itik lebih lebih tinggi dengan masa pemeliharaan lebih singkat (45 hari) dan tingkat kematian rendah sehingga diperoleh profit yang lebih baik.
\end{abstract}

Kata kunci: sistem budidaya intensif; itik lokal; peternak itik.

\begin{abstract}
The profit generated from the duck farming business is largely determined by management system. Following the problem identification through observation and Focus Group Discussions (FGD), facilitating intensification process in farming system was conducted to improve farmers knowledge in duck farming operation. This program amined to improve farmer knowledge on the intensive farming system thus farmer would gain more profit and sustainabile business. The mentorship program for iintensification process includes facilitation of intensive management system such sanitation and biosecurity processes, cages management, health management, and feed formulation as well as supervision on how to market the birds following harvest period. The mentoring process was carried out by raising 300 local Boyolali ducks for 45 days in two production cycles. The outputs obtained from the intensification program include improvements to sanitation standards and cage litter. In addition, the production obtained increased in accordance with the performance standards of local Boyolali ducks, as seen from the weight performance of $1.21 \mathrm{~kg}$ with a feed conversion ratio (FCR) of 3.28 and a mortality rate of $3.8 \%$. The cost benefit obtained from intensive duck farming is Rp. 1,783,500 in each period. It was concluded that intensive duck rearing had a higher impact on duck growth performance with a shorter maintenance period (45 days) and a lower mortality rate so that better profits were obtained.
\end{abstract}

Keywords: duck farmers; intensive farming system; local duck 


\section{PENDAHULUAN}

Pemberdayaan kegiatan ekonomi produktif bagi masyarakat dapat disesuaikan dengan potensi yang terdapat pada masingmasing daerah sesuai dengan kemampuan masyarakat. Pemberdayaan dapat dilakukan melalui berbagai pendekatan, mulai dari pembinaan, pelatihan, pembimbingan, serta pendampingan dalam usaha ekonomi produktif. Di pedesaan, usaha budidaya ternak dinilai strategis untuk dikembangkan karena berkontribusi langsung kepada masyarakat domestik, salah satunya adalah budidaya itik. Budidaya Itik sebagian besar dilaksanakan ditingkat pedesaan baik dipelihara ekstensif (digembalakan) maupun semi intensif (dikandangkan). Sistem budidaya itik di daerah Boyolali pada umumnya melibatkan usaha dari hulu hingga hilir berada dalam satu area dengan berbagai usaha meliputi usaha pemelihaaraan itik petelur penghasil telur tetas dan telur konsumsi, pembesaran itik (anak itik sampai umur 3 bulan dan umur 3-6/8 bulan), usaha pakan itik, usaha penetasan telur itik untuk dihasilkan anak itik umur sehari (Day Old Duck=DOD), hingga usaha produksi telur asin. Usaha Kecil Menengah (UKM) "Urip Farm" berlokasi di Desa Pentur, dengan lokasi geografis dekat dengan aliran sungai dan area persawahan yang luas mendukung usaha budidaya itik secara secara semi intensif. Lingkungan yang menunjang di wilayah ini sangat memungkinkan untuk dikembangkan menjadi sentra budidaya itik. Area persawahan yang tersedia juga merupakan sumber pakan utama dalam penggembalaan itik periode itik dara. Saat ini, unit usaha yang dikelola oleh UKM Urip Farm masih dijalankan secara tradisional dengan kapasitas kepemlikikan berkisar antara 50 - 100 ekor/ tiap peternak. Metode pemeliharan dilakukan masih sederhana, melalui penggembalaan di area persawahan tanpa banyak melibatkan sentuhan teknologi budidaya yang baik. Akibatnya, produktivitas yang dihasilkan masih sangat rendah dan tidak efisien. Hasil observasi yang dilakukan diperoleh data bahwa untuk mencapai bobot badan 1,2 kg, dibutuhkan waktu lebih dari dua (2) bulan. Bobot panen tersebut berada dibawah standar rata-rata performa itik secara umum (Ridwan dkk., 2019).

Selain itu, sistem penjualan dilakukan melalui tengkulak dengan sistem borongan yang menyebabkan peternak tidak mempunyai nilai tawar yang baik sehingga harga jual rendah. Dua masalah utama yang teridentifikasi tersebut dapat diperbaiki melalui proses pendampingan bertahap dari sisi hulu hingga hilir, sehingga peternak tidak hanya diharapkan dapat meningkatkan pengetahuan proses budidaya itik, namun juga berimplikasi pada peningkatan produktivitas serta nilai tawar hasil panennya. Melalui observasi kondisi tersebut, solusi yang ditawarkan adalah mengembangkan peternakan itik secara intensif, dengan perbaikan pakan, bibit, kesehatan, sanitasi, dan pemasaran. Tujuan pendampingan dan pelatihan budidaya itik intensif ini adalah untuk meningkatkan pengetahuan dan keterampilan peternak dalam menjalankan usaha budidaya itik secara intensif sehingga akan diperoleh keuntungan dan keberlangsungan usaha yang lebih baik..

\section{METODE}

\section{Proses pelaksanaan}

Kegiatan pengabdian pada masyarakat telah dilaksanakan selama 4 bulan, terhitung sejak Pebruari hingga Mei 2021. Lokasi kegiatan pada UKM "Urip Farm" yang terletak di Dusun Pentur, Desa Jagoan, Kecamatan Sambi, Kabupaten Boyolali, Jawa Tengah. Metode dan tahapan kegiatan pengabdian masyarakat pada UKM Mitra disajikan pada Gambar 1

Proses identifikasi permasalahan ditetapkan melalui kegiatan observasi. Kegiatan ini dilakukan secara langsung dan tidak langsung, yaitu melalui proses pengamatan langsung pada lokasi tujuan serta melalui informan yang mengetahui kondisi Desa tujuan tersebut.

Tahap selanjutnya yang dilakukan adalah pendampingan dan pelatihan metode pemeliharaan itik dengan metode intensif. Pada tahap ini, beberapa aspek teknis dilakukan, yaitu metode pemeliharaan itik secara intensif terlebih dahulu mempersiapkan kandang dengan menerapkan sanitasi dan biosecurity. Tim Pelaksana Pengabdian bersama UKM Mitra melakukan perbaikan sanitasi kandang dan memberikan materi yang berkaitan dengan pentingnya sanitasi dan biosecurity sederhana dan pengaruhnya untuk meningkatkan produktivitas itik. Pemberian materi dilakukan secara langsung kepada peternak sebagaimana disajikan pada Gambar 1.

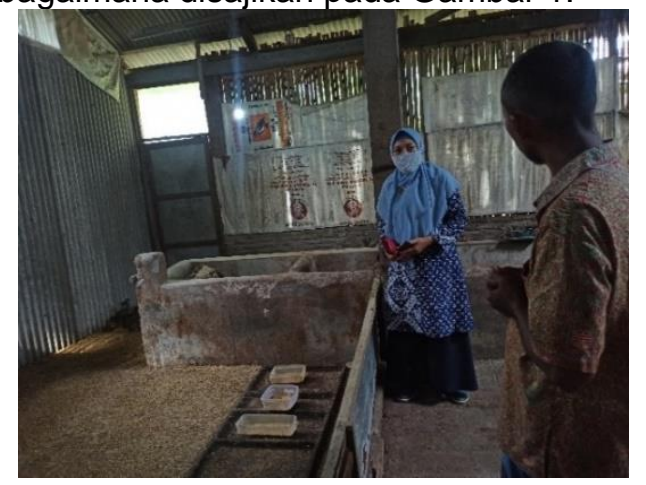

Gambar 1. Proses pemberian materi secara Ignsung kepad a peternak 
Kemudian, pemilihan litter menggunakan sekam padi ditujukan agar eksreta dapat terserap dengan baik dan menghindari pencemaran akibat gas amonia dan tumbuhnya jamur. Menyiapkan sarana dan prasarana penunjang seperti tempat pakan dan minum sesuai dengan kebutuhan total populasi itik yang dipelihara sekaligus tim Pelaksana Pengabdian bersama UKM Mitra melakukan penyiapan sarana dan prasarana kandang yang dibutuhkan. Tim pelaksana juga melakukan proses diseminasi teknologi pembuatan ransum itik yang dilakukan dengan pelatihan terlebih dahulu berkaitan dengan pembekalan pengetahuan tentang kebutuhan nutrien itik pedaging. Tim Pelaksana Pengabdian bersama UKM Mitra melakukan penyiapan sarana dan prasarana penyusunan ransum itik.

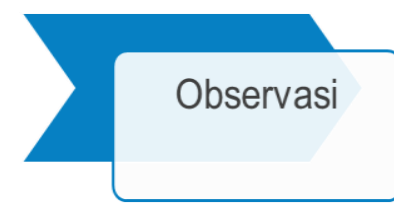

Observasi

wilayah

potensial,

penentuan objek

dan perumusan

masalah

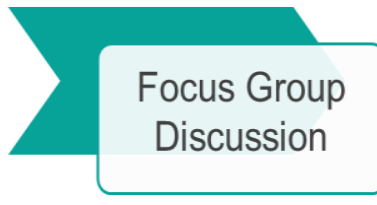

Proses identifikasi masalah secara lebih mendalam disertai penetapan strategi dan solusi

Gambar 2. Metode dan tahapan kegiatan pendampingan proses intensifikasi budidaya itik lokal Boyolali pada UKM "Urip Farm"

Proses identifikasi permasalahan ditetapkan melalui kegiatan observasi. Kegiatan ini dilakukan secara langsung dan tidak langsung, yaitu melalui proses pengamatan langsung pada lokasi tujuan serta melalui informan yang mengetahui kondisi Desa tujuan tersebut. Selanjutnya, tim pelaksana mengadakan dialog melalui kegiatan program Focuss Group Disscussion (FGD). FGD akan dilaksanakan oleh tim pelaksana kegiatan dengan UKM Mitra. Tujuan kegiatan FGD adalah untuk menetapkan rumusan masalah dan strategi bersama yang akan dilaksanakan untuk menyelesaikan masalah. Kegiatan FGD juga digunakan untuk mengkoordinasikan pelaksanaan kegiatan, penggalian potensi keterlibatan mitra serta pihak pendukung lainnya untuk mengatasi permasalahan yang ada, serta evaluasi setiap tahapan pelaksanaan kegiatan. Hasil FGD akan disepakati kegiatan yang direncanakan, rencana waktu pelaksanaan dan target capaian per kegiatan yang akan dilakukan.

Tahap selanjutnya yang dilakukan adalah fasilitasi pelatihan metode pemeliharaan itik dengan metode intensif. Pada tahap ini, beberapa aspek teknis dilakukan, yaitu metode pemeliharaan itik secara intensif terlebih dahulu mempersiapkan kandang dengan menerapkan sanitasi dan biosecurity. Tim Pelaksana Pengabdian bersama UKM Mitra melakukan perbaikan sanitasi kandang dan memberikan materi yang berkaitan dengan pentingnya sanitasi dan biosecurity sederhana dan pengaruhnya untuk meningkatkan produktivitas itik. Kemudian, pemilihan litter menggunakan sekam padi ditujukan agar eksreta dapat terserap dengan baik dan menghindari pencemaran akibat gas amonia dan tumbuhnya jamur. Menyiapkan sarana dan prasarana penunjang seperti tempat pakan dan minum sesuai dengan kebutuhan total populasi itik yang dipelihara sekaligus tim Pelaksana Pengabdian bersama UKM Mitra melakukan penyiapan sarana dan prasarana kandang yang dibutuhkan. Tim pelaksana juga melakukan proses diseminasi teknologi pembuatan ransum itik yang dilakukan dengan pelatihan terlebih dahulu berkaitan dengan pembekalan pengetahuan tentang kebutuhan nutrien itik pedaging. Tim Pelaksana Pengabdian bersama UKM Mitra melakukan penyiapan sarana dan prasarana penyusunan ransum itik.

\section{Proses pengawasan dan evaluasi program}

Tahap monitoring dilaksanakan secara berkala untuk memastikan manajemen budidaya yang dilaksanakan sesuai dengan cara budidaya itik yang baik. Monitoring juga dilakukan untuk memberikan edukasi serta solusi atas kendala yang dihadapi peternak selama pemeliharaan. Berbagai aspek operasional budidaya seperti pemberian pakan, air minum, sanitasi, dan penilaian kualitas litter hingga pengecekan catatan penimbangan 
mingguan dilakukan oleh Tim Pelaksana sampai masa panen.

Saat periode pemeliharaan berakhir, evaluasi dilakukan pada performa atau produksi yang dihasilkan serta pada hasil usaha yang diperoleh. Selanjutnya, peternak melaksanakan pemeliharaan periode kedua dengan modal yang telah diperoleh dari hasil penjualan periode pertama. Model ini nantinya akan dilakukan secara bergilir pada peternak lainnya sehingga diseminasi teknologi dan transfer pengetahuan serta pengalaman dari peternak satu ke peternak lain dapat dilakukan.

Metode ini dinilai efektif karena model percontohan dapat memberikan motivasi pada peternak lain untuk mengadopsi sistem budidaya yang telah diberikan sehingga ada peralihan secara berkala terhadap sistem pemeliharaan non-intensif menjadi semiintensif dan intensif.

\section{HASIL DAN PEMBAHASAN \\ Proses Focus Group Discussion}

Kegiatan Focuss Group Disscussion (FGD) dilaksanakan secara terbatas antara peternak individu dengan tim pengabdi di rumah peternak. Tujuan kegiatan FGD adalah untuk menetapkan rumusan masalah dan strategi bersama yang akan dilaksanakan untuk menyelesaikan masalah. Kegiatan FGD juga digunakan untuk mengkoordinasikan pelaksanaan kegiatan, penggalian potensi keterlibatan mitra serta pihak pendukung lainnya untuk mengatasi permasalahan yang ada, serta evaluasi setiap tahapan pelaksanaan kegiatan. Hasil FGD akan disepakati kegiatan yang direncanakan, rencana waktu pelaksanaan dan target capaian per kegiatan yang akan dilakukan. Gambaran kegiatan FGD terbatas disediakan pada Gambar 3.

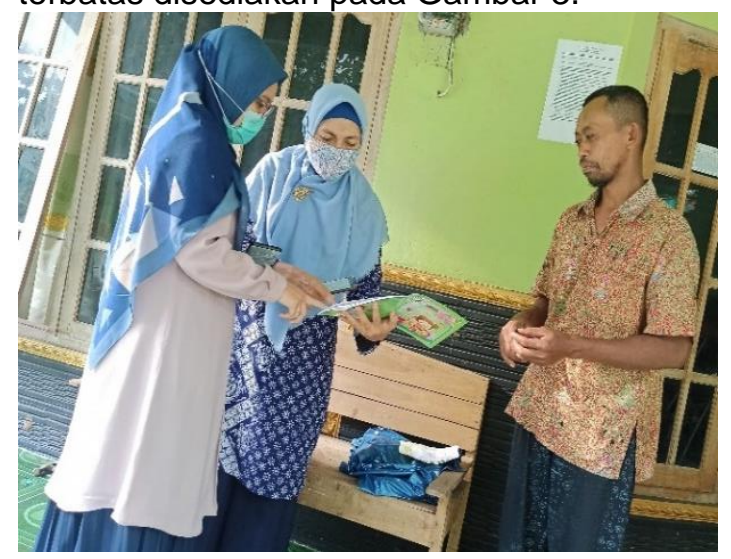

Gambar 3. Kegiatan FGD antara tim pengabdi dan peternak.

\section{Pendampingan Proses Pemeliharaan}

Pemeliharaan secara intensif adalah sistim pemeliharaan ayam tanpa menyediakan area umbaran tetapi dengan cara dikandangkan secara terus menerus sehingga semua kandungan zat-zat makanan harus disediakan secara cukup dalam ransumnya. Itik yang dipelihara oleh peternak bapak Suyamto awalnya dilakukan secara semi intensif yang berpindah pada pola intensif. Perbaikan dilakukan mulai dari kandang, manajemen pemeliharaan, pakan dan kesehatan itik.

Kandang peternak yang berlokasi di Sambi Boyolali berukuran 5 x 10 m berdinding tembok dan beratap asbes dengan kapasitas 300 ekor. Ventilasi kandang cukup dengan sirkulasi udara dan sinar matahari dapat masuk dalam kandang, karena perkandangan merupakan salah satu faktor penting yang menentukan baik buruknya performa ternak yang akan dipelihara didalamnya (Czarick, 2019). Nyaman tidaknya ternak didalam kandang tergantung dari rancangan desain kandang yang dibuat. Luas kandang merupakan perkalian antara kebutuhan kandang perekor dengan jumlah itik yang akan dipelihara. Ketidakseuaian ukuran kandang dengan kapaitas kandang akan berakibat pada performa ternak yang dipelihara. Kandang yang nyaman membuat aktivitas ternak lebih nyaman dan memperbaiki efisiensi penggunaan nutrien bagi itik. Letak kandang juga jauh dari pemukiman penduduk sehingga tidak mengganggu lingkungan sekitarnya akibat dampak menanganan limbah.Kondisi perkandangan yang ideal untuk densitas kepadatan kandang 8-11 ekor/m², kondisi temperatur ruangan $32,0-35,5^{\circ} \mathrm{C}$ dan kelembaban $60-70 \%$ (USDA, 2013).

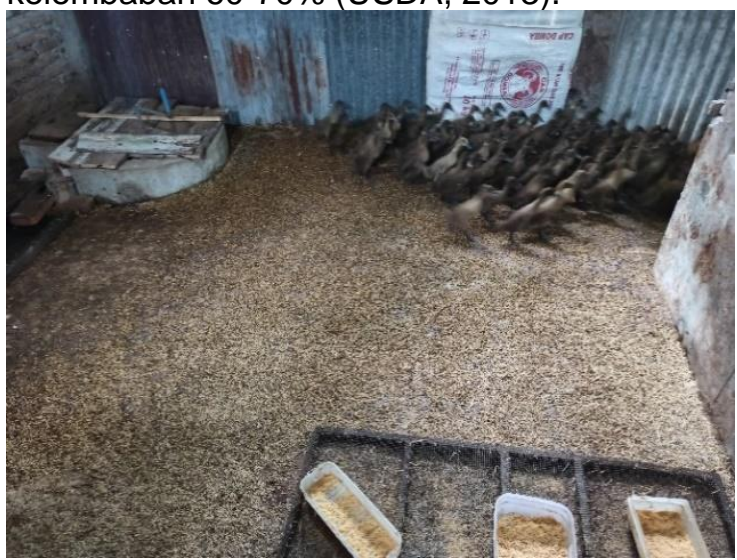

Gambar 4. Litter dan tempat minum serta bentuk perkandangan yang digunakan untuk pemeliharaan

Manajemen perkandangan meliputi fungsi kandang, persyaratan kandang dan kontruksi kandang. Bahan bangunan kandang yang digunakan disesuaikan dengan lama waktu penggunaan kandang. Semakin lama penggunaan kandang maka bahan kandang yang dipilih adalah bahan-bahan yang kuat dan kokoh misalnya kayu, besi, baja dan lain lain. 
Bahan-bahan yang digunakan ini akan memberikan kandang yang nyaman untuk ternak.

Pemilihan bahan kandang mengacu pada masing-masing sifat bahan yang mampu membuat ternak nyaman didalamnya.Pembuatan tiang dari beton (cor beton) diharapkan umur kandang relatif lama.Bahan tiang utama kandang dari beton (cor beton) kandang lebih kokoh dan penggunaan bahan kandang untuk ventilasi dengan menggunakan kayu atau bambu akan lebih mudah dalam perbaikannya. Atap kandang model monitor dengan ventilai terbuat dari bingkai kayu dan kawat harmonika. Lantai kandang di buat dari semen.

\section{Pendampingan Manajemen Pemeliharaan} Kualitas itik potong dimulai dari pemeliharan anak umur satu hari (DOD). Broder box disiapkan dimana setiap $1 \mathrm{~m}^{2}$ berkapasitas 100 ekor dengan bolam lampu sebagai pemanas dengan suhu $35^{\circ} \mathrm{C}$ yang dinyalakan 2 jam sebelum DOD di masukkan. Pemanas (brooder) berfungsi untuk menjaga kestabilan suhu kandang dan sistem kekebalan tubuh DOD yang belum stabil dalam fungsinya (Aviagen, 2019). Air minum pada hari pertama ditambahkan antibiotik dan selanjutnya diberikan vitamin.Periode starter di dalam brooder selama 14 hari. Setelah itik berumur satu minggu suhu diturunkan $30^{\circ} \mathrm{C}$. DOD yang sehat akan tampak lincah dan bergerak aktif. Pemberian pakan periode starter pada minggu pertama diberikan sesering mungkin secara adlibitum. Pakan yang diberikan berupa pakan crumble dengan kandungan protein $21 \%$. DOD diturunkan dari kandang brooder ke kandang postal setelah berumur 2 minggu. Sebelumnya, kandang postal telah dipersiapkan dengan menutup lantai dengan kapur mati dan sekam. Sekam mempunyai daya serap tinggi dan mempertahankan suhu kandang. Saat ayam diturunkan ke kandang postal terlebih dahulu dipersiapkan pakan dan minum dan tirai kandang kandang (Muharlien dkk., 2012).

Pemeliharaan ternak secara intensif harus diikuti dengan pencegahan ataupun pengendalian penyakit (Adnyana, et.al, 2016). Sesuai dengan Payne et al. (2002) yang menyatakan bahwa pengendalian ataupun pencegahan penyakit sangat penting sehingga dapat mengatasi atau mencegah terjadinya penularan penyakit ataupun timbulnya penyakit. Secara rutin, dalam budidaya itik pedaging ini secara rutin melakukan vaksinasi sehingga itik terhindar dari virus dan penyakit.

Salah satu faktor penentu keberhasilan suatu usaha budidaya itik adalah faktor pakan (Gading et al., 2020), disamping faktor genetik dan tatalaksana pemeliharaan (Sidadolog, 2018). Biaya pakan dalam suatu usaha peternakan khususnya teknik pemeliharaan secara intensif ternak ayam kampung merupakan komponen terbesar dari total biaya produksi yang harus dikeluarkan peternak selama proses produksi yaitu sekitar 60 sampai $70 \%$. Oleh karena itu agar usaha peternakan ternak dapat berhasil dengan baik, yaitu ternak dapat tumbuh dan berproduksi dengan optimal sesuai dengan yang diharapkan dengan tingkat keuntungan yang maksimum, maka faktor pakan harus mendapat perhatian yang cukup serius, terutama kualitas dan harga pakan (Suprayogi et al., 2017).

Pakan diberikan untuk memenuhi kebutuhan hidup pokok dan pertumbuhan itik karena mengandung berbagai nutrient lengkap seperti karbohidrat, protein, lemak, serat kasar, vitamin, mineral dan air. Pakan itik pedaging yang digunakan terdiri atas dua jenis berdasarkan fase pemeliharaan yaitu pakan untuk periode starter (0-2 minggu) dan finisher (3 minggu sampai panen). Pakan itik pada saat periode starter diberikan dalam bentuk crumbel dengan kadar protein $21 \%$, yang telah memenuhi standar nasional Indonesia (SNI, 2018) untuk mendukung pertumbuhan dari DOD. Pakan finisher diberikan dengan kadar protein $16 \%$. Bobot badan itik potong yang dipelihara menunjukkan pertumbuhan yang baik karena telah sesuai dengan standar. Performa itik pedaging pada saat pemeliharaan disajikan pada Tabel 1.

Tabel 1. Rerata konsumsi dan pertambahan bobot badan itik yang dipelihara secara intensif

\begin{tabular}{cccc}
\hline $\begin{array}{c}\text { Umur } \\
\text { (minggu) }\end{array}$ & $\begin{array}{c}\text { Bobot } \\
\text { badan } \\
\text { (gram) }\end{array}$ & $\begin{array}{c}\text { Konsumsi } \\
\text { pakan } \\
\text { kumulatif } \\
\text { (gram) }\end{array}$ & FCR \\
\hline 1 & 190 & 155 & 0.82 \\
2 & 310 & 450 & 1.45 \\
3 & 475 & 950 & 2.00 \\
4 & 690 & 1660 & 2.41 \\
5 & 920 & 2500 & 2.72 \\
6 & 1105 & 3515 & 3.18 \\
7 & 1210 & 3970 & 3.28 \\
\hline
\end{tabular}

Sumber data: Data primer (diolah, 2021); FCR= Feed conversion ratio

Data pertumbuhan itik menunjukkan perkembangan yang baik terlihat dari capaian bobot badan mingguan, konsumsi pakan, dan FCR yang dicapai. Pemeliharaan yang dilakukan selama 45 hari diperoleh rataan bobot panen sebesar 1.210 gram, yang menunjukkan peningkatan signifikan dibandingkan dengan pola pemeliharaan yang 
dilakukan sebelumnya secara non intensif. Melalui pemeliharaan non intensif, waktu yang dibutuhkan untuk mencapai bobot diatas $1 \mathrm{~kg}$ dibutuhkan waktu yang jauh lebih lama. Tingkat deplesi dari itik yang dipelihara secara intensif dilaporkan sebesar 3,8\%, dimana persentase tersebut dikategorikan wajar karena masih dibawah 5\%.

\section{Analisis usaha hasil panen}

Hasil analisa ekonomi usaha penggemukan itik yang telah dilakukan secara intensif ditampilkan pada Tabel 2.

Tabel 2. Analisa Biaya dan Penerimaan Budidaya Ayam Kampung Intensif

\begin{tabular}{|c|c|c|}
\hline Uraian & Kuantitas & $\begin{array}{r}\text { Jumlah } \\
(\mathbf{R p})\end{array}$ \\
\hline DOD (ekor) & 300 & 1.500 .000 \\
\hline $\begin{array}{l}\text { Pakan (kg) } \\
\text { Obat-obatan (1 } \\
\text { Paket) }\end{array}$ & 1.181 & 7.676 .500 \\
\hline $\begin{array}{l}\text { Listrik (bulan) } \\
\text { Tenaga kerja ( } 2 \\
\text { bulan) }\end{array}$ & 2 & 800.000 \\
\hline Depresiasi peralatan & & 20.000 \\
\hline Biaya pokok produksi & & 10.396 .500 \\
\hline $\begin{array}{l}\text { Penjualan Itik potong } \\
\text { Keuntungan } 1 \\
\text { periode }\end{array}$ & 348 & $\begin{array}{r}12.180 .000 \\
\mathbf{1 . 7 8 3 . 5 0 0}\end{array}$ \\
\hline
\end{tabular}

Pakan berkontribusi sebesar 73,8\% dalam pemeliharaan ini, yakni sebesar Rp. 7,676 juta dari total biaya produksi sebesar Rp. 10,396 juta. Sementara itu, komponen biaya lain seperti DOD atau bibit, obat-obatan hingga tenaga kerja menyumbang sekitar $25 \%$ biaya produksi. Hasil keuntungan yang diperoleh dari pemeliharaan 300 ekor itik yaitu Rp. 1,78 juta (untung). Sebelum dilakukan pendampingan budidaya intensif, proses evaluasi usaha tidak pernah dilakukan sehingga tidak bisa diprediksi secara pasti kenaikan keuntungan yang diperoleh setelah adanya pendampingan usaha. Akan tetapi, hasil wawancara dengan peternak diketahui bahwa harga jual tidak pernah lebih tinggi dari saat ini. Peternak mengaku bahwa keuntungan yang diperoleh saat ini jauh lebih tinggi dibandingkan sebelumnya yang seringkali hanya balik modal. Pemasaran hasil panen yang diperoleh dari kegiatan ini adalah pengusaha olahan daging itik binaan Tim Pelaksana sehingga proses pemasaran mudah dilakukan. Saat ini, mitra pembeli hasil panen dapat menampung seluruh itik yang dipanen. Kedepan, pemasaran masih potensial dilakukan pada rumah makan atau restoran yang tersebar di sekitar kawasan Solo Raya.

\section{SIMPULAN DAN SARAN}

Kegiatan pendampingan usaha budidaya itik secara intensif telah berhasil meningkatkan pengetahuan dan keterampilan peternak dalam berbagai aspek operasional pemeliharaan itik. Manajemen pemeliharaan itik pedaging secara intensif memberikan dampak pertumbuhan itik yang lebih tinggi dengan masa pemeliharaan yang lebih singkat (45 hari) dengan tingkat mortalitas yang dapat dikendalikan yaitu dibawah 5\%. Sebelum diterapkan pola pemeliharaan intensif, umur panen diatas 60 hari. Profit yang dihasilkan dari pola pemeliharaan secara intensif mampu memberikan keuntungan yang layak dibandingkan sebelumnya sehingga usaha budidaya itik pedaging layak ditingkatkan dan berpotensi dikembangkan lebih jauh menjadi sebuah sentra peternakan itik Boyolali.

\section{UCAPAN TERIMA KASIH}

Penulis mengucapkan terima kasih kepada Lembaga Penelitian dan Pengabdian kepada Masyarakat Universitas Sebelas Maret (LPPM UNS) yang telah mendanai kegiatan pengabdian masyarakat ini melalui skema pengabdian kepada masyarakat hibah grup riset (PKM HGR-UNS) (Nomor kontrak: 261/UN27.22/HK.07.00/2021), Dana Non Anggaran Pendapatan dan Belanja Negara UNS Tahun Anggaran 2021.

\section{DAFTAR RUJUKAN}

Aviagen. (2019). Management Handbook. Aviagen Ltd: Alabama, USA.

Czarick, M. (2019). Evaluation of the Combined Effects of Air Movement and Reduced House Relative Humidity on Bird Health and Welfare in the Early Phase of Commercial Broiler. Retrieved from https://www.uspoultry.org/research/res proj/PROJ 705.html

Gading, B. M. W. T., Agus, A., Irawan, A., \& Panjono. (2020). Growth performance, hematological and mineral profile of post-weaning calves as influenced by inclusion of pelleted-concentrate supplement containing essential oils and probiotics. Iranian Journal of Applied Animal Science, 10(3). 461468.

Muharlien, Achmanu, R. Rachmawati. (2012). Meningkatkan produksi ayam pedaging melalui pengaturan proporsi sekam, pasir dan kapur sebagai litter. TERNAK TROPIKA: Journal of Tropical Animal Production. 12 (1). 38-45.

Ridwan, M., Sari, D., Andika, R.D., Candra, A.A. dan Maradon, G.G. (2019). Usaha Budidaya Itik Pedaging Jenis Hibrida 
dan Peking. Jurnal Peternakan Terapan. 1(1). 8-10.

Sidadolog, J. H. P. S. (2018). Beternak itik petelur dengan pakan berbasis limbah lokal. Yogyakarta: UGM Press.

Standar Nasional Indonesia. (2018). Pakan Itik Pedaging Penggemukan. Jakarta: BNSP.

Suprayogi, W. P. S., Sudibya, E.H. and Susilo. (2017). Performa itik lokal jantan (Anas plathyrynchos) yang diberi pakan suplemen. Caraka Tani: Journal of Sustainable Agriculture. 32 (1). 35-41.

USDA. (2013). Poultry industry manual. Maryland, USA. 